\title{
Comprehensive Survey of the Distribution of Colour and Phenolics of Different Red Grape Wine Vineyard Blocks from the Robertson Area in South Africa
}

H. van der Merwe ${ }^{1}$, H. Nieuwoudt ${ }^{2}$, D. de Beer ${ }^{3}$, W.J. du Toit ${ }^{*}$

(1) Department of Viticulture and Oenology, Stellenbosch University, Private Bag X1, Matieland, 7602, South Africa

(2) Institute for Wine Biotechnology, Stellenbosch University, Private Bag X1, Matieland, 7602, South Africa

(3) Agricultural Research Council (ARC)-Infruitec-Nietvoorbij, Private Bag X5016, Stellenbosch, 7599, South Africa

Submitted for publication: September 2011

Accepted for publication: December 2011

Key words: Grape color, phenolic content, Robertson Region, red grapes

\begin{abstract}
Colour and phenolic content of red grapes are two of the most important constituents required to produce a quality red wine. In the Robertson grape growing area, difficulty is sometimes experienced with colour development of grapes. This is especially linked to location and most probably greatly influenced by season. Forty four vineyard blocks of the cultivars Pinotage, Merlot, Cabernet Sauvignon and Shiraz, were studied over 3 seasons primarily to focus on colour and phenolic content, but secondly on total soluble solids, titratable acidity and $\mathrm{pH}$ of the grapes. High performance liquid chromatography and spectrophotometric methods were used to determine various colour and phenolic parameters present at harvest. This data was used to indicate how colour and phenolic constitution of a part of the Robertson grape growing area was distributed in relation to various factors, such as cultivar and season. GPS points were used to map data for the blocks visually. Results showed variable colour and phenolic content for these grapes based on blocks and phenolic compounds investigated. Shiraz displayed a wider distribution of certain phenolic compounds over the three seasons than the other 3 cultivars. Seasonality had a great influence on these results, with outlying blocks being identified.
\end{abstract}

\section{INTRODUCTION}

Robertson is one of the warmer viticultural regions of South Africa. Grape growers in the Robertson area are faced with average maximum temperatures exceeding $27^{\circ} \mathrm{C}$ during the ripening phase of the grapes during the harvesting season. Grapes from certain vineyards in the Robertson area have a different colour concentration than those cultivated in cooler areas. In 1974 Winkler and associates already found that temperatures too hot or too cold are associated with poor colour development in berries. They also classified the climates of winegrowing regions, and according to this system Robertson falls in the IV category (Categories I-V, low to high temperatures) (Hunter \& Bonnardot, 2011).

The optimum temperature range for anthocyanin synthesis was found to be $17^{\circ} \mathrm{C}$ to $26^{\circ} \mathrm{C}$ (Prie, 1997). It has also been determined that average maximum temperatures of $30^{\circ} \mathrm{C}$ to $35^{\circ} \mathrm{C}$ could lead to no colour development irrespective of night temperatures in those periods (Kliewer, 1970; Kliewer \& Torres, 1972). Some studies have claimed that 'grapes do not produce quality fruit when grown in extreme heat conditions' (Turner, 2009) which is exactly what must be overcome, by finding the balance between sugar and phenolic ripeness of the grapes, to obtain the highest quality. Numerous factors influence flavonoid biosynthesis in plants, including light, temperature, altitude, soil type, water availability, nutrition, microbial interactions, pathogenesis, wounding, defoliation, plant growth regulators and various developmental processes. Despite the influence from all the above mentioned, the greatest influences on the flavonoid content of any cultivar are thought to be site, season, water and temperature (Bakker et al., 1986; Gonzalez-San Jose et al., 1990; Revilla et al., 1997; McDonald et al., 1998; De Freitas \& Glories, 1999; Guidoni et al., 2002; Ojeda et al., 2002). If, for a specific site, the soil and viticultural practices are the same and nutrition is adequate, it could be postulated that primary seasonal differences will be due to climatic factors such as sunlight and temperature (Downey et al., 2005).

The importance of phenolic compounds in the quality of wines has been demonstrated many times over in studies (Peynaud, 1996). Phenolic compounds are firstly responsible

*Corresponding author: wdutoit@sun.ac.za

Acknowledgements: The authors thank Robertson Winery, National Research Foundation (NRF) and Thrip for funding, Martin Kidd for statistical analyses and F.C. Basson for GPS maps 
for the colour of wine. The colour of wine could influence the preference of wine consumers (Somers \& Evans, 1974) and is an indication of the amount of oxygen exposure of the wine (Singleton, 1987). In some cultivars, colour has also been linked directly to wine quality (Du Toit et al., 2006). Phenolic compounds secondly play an important role in the taste and mouth feel properties of wine. As an example, bitterness and astringency are linked to flavan-3-ols (otherwise known as catechins). The lower molecular weight flavan-3-ols relate to bitterness, whilst the higher molecular weight, protein bound flavan-3-ols relates to astringency in wine (Rossi \& Singleton, 1966; Robichaud \& Noble, 1990). Phenolic compounds thirdly influence the odour of wines directly through vanillin, ethyl phenols and vinyl phenols. The contribution of volatile phenols to wine could be positive or negative, dependent on compound composition and concentration. Phenolic compounds fourthly determine the oxidative ability of a wine and therefore the maturing potential.

Studies concentrating on the amount of colour in Robertson grapes and wines to date were not comprehensive enough to reflect variation due to seasonal and geographical location. A 2005 preliminary study on the relationship between grape and wine colour in the Robertson region only involved three cultivars over one season (Marais \& October, 2005). Therefore, more information on this topic will not only add to the scientific knowledge base but could also practically contribute to the industry.

The primary aim of this study was to evaluate the colour and phenolic composition of a large number of vineyard blocks over time. Forty four vineyard blocks consisting of Pinotage, Merlot, Cabernet Sauvignon and Shiraz were studied over three seasons primarily with regards to colour and phenolic content, but also noting total soluble solids, titratable acidity and $\mathrm{pH}$. A wide range of high performance liquid chromatography (HPLC) and spectrophotometric (spec) analyses for colour and phenolic characteristics were used to characterise grapes originating from these blocks. GPS coordinates were used to map the blocks in relationship to colour and phenolic content and its distribution over the three seasons.

\section{MATERIALS AND METHODS Vineyards}

Pinotage (P1-9), Merlot (M1-12), Cabernet Sauvignon (C1-12) and Shiraz (S1-11) blocks from the Robertson grape growing area in South Africa were selected for this survey (Fig. 1, Table 1). While the cultivars (cv.) and blocks remained the same over the seasons, the sample block quantity increased from 2007 to 2008 and 2009. The blocks varied in size, orientation, age, rootstocks, degree of virus infection and soil characteristics (Table 1).

Weather stations located in this area were utilized to obtain temperature and rainfall data. Real GPS coordinates were used to display the orientation of the stations with regards to the blocks on a topographical map containing information of the towns, roads, rivers and mountain ranges of the area (Fig. 1). The data was taken for the periods 2007 -2009 and for the months of January to April and for these, temperature and rainfall averages were determined.

Grapes were sampled from demarcated vines in selected blocks at commercial harvest time. Each vineyard block used in this survey was subdivided into two to three sites, depending on the size of the vineyard (Fig. 2). Each site was selected at least five rows from the outside of the block and a minimum of two sections from the start of each row inside the block. The sites consisted of 40 vines from which five berries each were picked, which resulted in a sample size

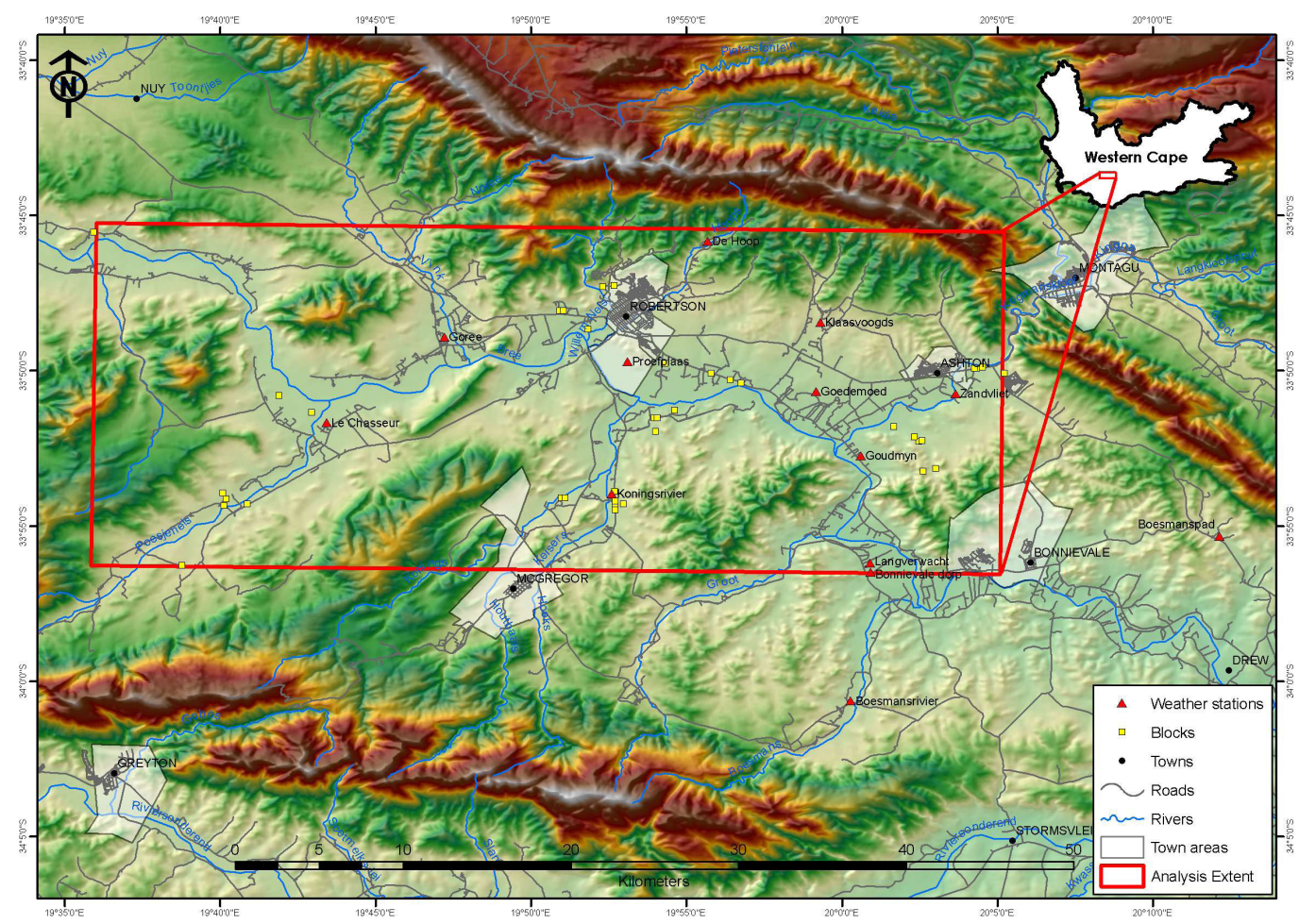

FIGURE 1

A topographical Robertson area indicating the coordinates of the weather stations and vineyard blocks evaluated during this survey (red square). 
of 200 berries per site, thus 600 berries per block (Fig. 2). The berries were removed from the top, bottom, furthest left, furthest right and from the backside of the growth zone from each vine. Of the 200 berries collected from each site 50 berries were weighed and homogenised (IKA ${ }^{\circledR}$-Werke GMBH \& CO.KG, Staufen, Germany) at $20000 \mathrm{rpm}$ for four minutes. A mini trial was initially done with regards to the time needed for complete homogenisation. A sub sample were immediately analysed for $\mathrm{pH},{ }^{\circ} \mathrm{B}$, TA and the rest of the berries were stored as homogenates at $-20^{\circ} \mathrm{C}$.

\section{Analyses of grape samples}

An ethanol extraction $(50 \% \mathrm{v} / \mathrm{v})$ was made using $1 \mathrm{~g}$ homogenate and $10 \mathrm{~mL}$ solution. This was left to extract for 1 hour during which the samples were shaken every $10 \mathrm{~min}$. After centrifugation $10 \mathrm{~mL} 1 \mathrm{M} \mathrm{HCl}$ was added to $1 \mathrm{~mL}$ of the supernatant and left for 3 hours after which the samples were analysed at 520 and $280 \mathrm{~nm}$ on the spectrophotometer (Analytic Jena Specord 50 UV/VIS Spectrophotometer;
Jena, Germany). The resulting anthocyanin and total phenol content were used to validate the quality of the homogenate. The coefficient of variation for anthocyanins concentration $(\mathrm{mg} / \mathrm{g})$ decreased from $10 \%$ to below $5 \%$ with a homogenisation time increase from three to four minutes (data not shown).

Anthocyanin and total phenol concentrations of the grapes were analysed using Iland's method of grape extraction and acidification followed by measuring the absorbance at 280 $\mathrm{nm}$ and $520 \mathrm{~nm}$ (Iland et al., 2000). Chemicals used were 1 M HCL (32\% Hydrochloric acid, Merck Chemicals PTY, Ltd) and 50\% ethanol (Absolute Ethanol, Merck).

The grape tannin analyses were done by using methyl cellulose precipitation (MCP Tannins, mg/L, Sarneckis et al., 2006) in 2007 and bovine serum albumin precipitation (BSA Tannins, mg/L; Harbertson et al., 2003) in 2008/2009. This study chose the BSA method for further analyses because it found the method more reliable and repeatable than the MCP method. For the MCP method the study used methyl cellulose

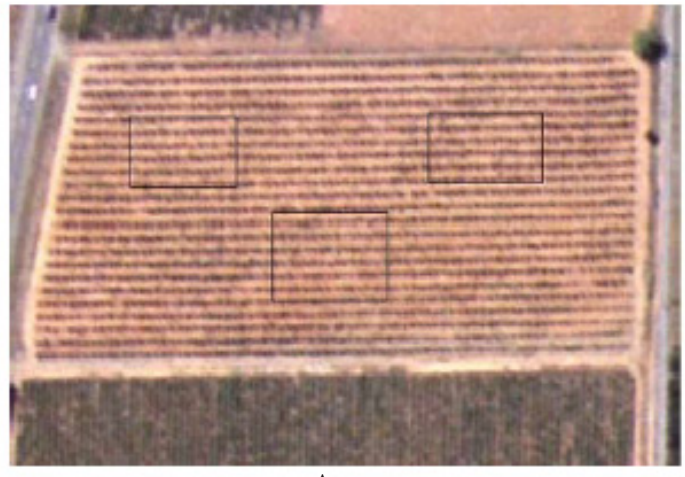

A

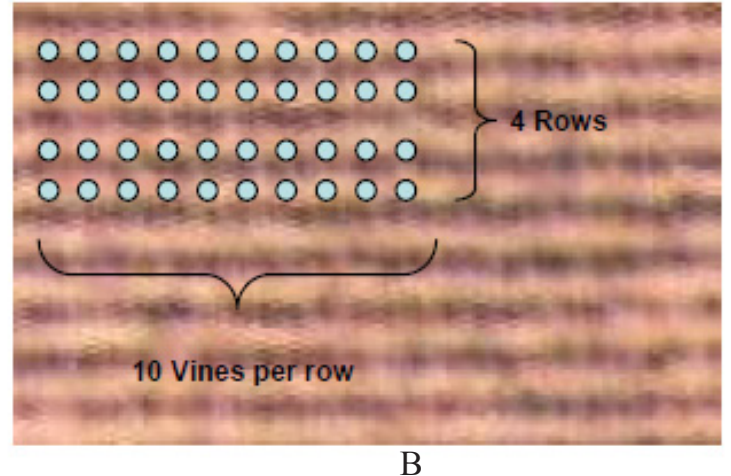

B

FIGURE 2

Each vineyard block was divided into 3 sites for sampling (A). Each of these sites was divided into 4 rows containing 10 vines, therefore 40 vines per site (B).

TABLE 1

The Pinotage (P1-9), Merlot (M1-12), Cabernet Sauvignon (C1-12) and Shiraz (S1-11) blocks chosen for this survey (20072009), their location and cultivation specifics.

\begin{tabular}{|c|c|c|c|c|c|c|c|}
\hline Sample code: & Size $\mathrm{Ha}^{1}$ & Orientation $^{2}$ & Age (2007) ${ }^{3}$ & Rootstock $^{4}$ & $\begin{array}{l}\text { Virus infection } \\
\text { (Leaf roll) }\end{array}$ & Soil & Trellis system $^{5}$ \\
\hline P1 & 0.76 & SE, Med slope & 10 & $\mathrm{R} 110$ & Clear & Karoo & 4WEP \\
\hline $\mathrm{P} 2$ & 2.55 & Flat & 11 & R99 & Clear & Karoo & 5WEP \\
\hline P3 & 1.70 & Flat & 11 & $\mathrm{R} 110$ & Clear & Karoo & 5WEP \\
\hline P4 & 2.40 & NW, Med slope & 10 & 101-14 MGT & Clear & Karoo/Shale & 5WEP \\
\hline P5 & 3.00 & SW, Med slope & 11 & $\mathrm{R} 110$ & Low & Karoo/Shale & $5 \mathrm{WEP}$ \\
\hline P6 & 7.50 & SE, Med slope & 12 & Varia & Clear & Karoo/Shale & 4WEP \\
\hline $\mathrm{P} 7^{6}$ & 1.18 & Flat & 10 & 101-14 MGT & Clear & Karoo & 4WEP \\
\hline $\mathrm{P} 8^{6}$ & 3.37 & Flat & 11 & $\mathrm{R} 110$ & Clear & Karoo & 4WEP \\
\hline $\mathrm{P}^{6}$ & 2.58 & Flat & 12 & $\mathrm{R} 110$ & Medium & Karoo & 4WEP \\
\hline M1 & 12.20 & Flat & 8 & R110 & Clear & Soft Karoo/Alluvial & 6WEP \\
\hline M2 & 6.70 & Flat & 11 & $\mathrm{R} 110$ & Clear & Karoo & 5WEP \\
\hline M3 & 3.36 & Flat & 12 & R99 & Medium & Rock Terrace & 5WEP \\
\hline M4 & 6.40 & Flat & 8 & R110 & Low & Soft Karoo/Alluvial & 4WEP \\
\hline M5 & 3.50 & Flat & 8 & $\mathrm{R} 110$ & Low & Soft Karoo/Alluvial & 4WEP \\
\hline M6 & 8.20 & Flat & 8 & US 8-7 & Low & Karoo & $5 \mathrm{WEP}$ \\
\hline $\mathrm{M} 7^{6}$ & 1.76 & Flat & 11 & $\mathrm{R} 110$ & Low & Alluvial & 4WEP \\
\hline M $8^{6}$ & 1.93 & Flat & 13 & R99 & Low & Rock/Karoo & 4WEP \\
\hline
\end{tabular}




\begin{tabular}{|c|c|c|c|c|c|c|c|}
\hline Sample code: & Size $\mathrm{Ha}^{1}$ & Orientation $^{2}$ & Age $(2007)^{3}$ & Rootstock $^{4}$ & $\begin{array}{l}\text { Virus infection } \\
\text { (Leaf roll) }\end{array}$ & Soil & Trellis system $^{5}$ \\
\hline $\mathrm{M}^{6}$ & 3.05 & Flat & 12 & R99 & Low & Rock/Karoo & 4WEP \\
\hline $\mathrm{M} 10^{6}$ & 3.57 & Flat & 12 & $\mathrm{R} 110$ & Medium & Karoo & 4WEP \\
\hline $\mathrm{M}_{11}{ }^{6}$ & 1.15 & Flat & 10 & $\mathrm{R} 110$ & $100 \%$ infected & Alluvial & 4WEP \\
\hline $\mathrm{M} 12^{6}$ & 4.90 & Flat & 10 & R110 & Medium & Karoo & $5 \mathrm{WEP}$ \\
\hline $\mathrm{C} 1$ & 3.49 & Flat & 9 & US 8-7 & Clear & Karoo/Shale & $2 \mathrm{~W} \mathrm{H}$ \\
\hline $\mathrm{C} 2$ & 4.14 & Flat & 9 & $\mathrm{R} 110$ & Clear & Karoo & 4WEP \\
\hline $\mathrm{C} 3$ & 4.52 & NE, Med slope & 17 & 101-14 MGT & $100 \%$ infected & Karoo/Shale & $5 \mathrm{WEP}$ \\
\hline $\mathrm{C} 4$ & 5.04 & Flat & 11 & R110 & Clear & Karoo/Shale & 4WEP \\
\hline $\mathrm{C} 5$ & 2.24 & Flat & 11 & R110 & Clear & Karoo & $5 \mathrm{WEP}$ \\
\hline C6 & 3.80 & Flat & 10 & US 8-7 & Clear & Karoo/Shale & 4WEP \\
\hline $\mathrm{C} 7$ & 2.40 & NW, Med slope & 10 & 101-14 MGT & Clear & Karoo/Shale & $5 \mathrm{WEP}$ \\
\hline $\mathrm{C} 8$ & 11.87 & Flat & 10 & Varia & Medium & Karoo/Shale & $5 \mathrm{WEP}$ \\
\hline C9 & 2.16 & Flat & 8 & R110 & Clear & Karoo & 4WEP \\
\hline $\mathrm{C} 10$ & 13.36 & S, Steep slope & 12 & 101-14 MGT & Medium & Karoo/Shale & $5 \mathrm{WEP}$ \\
\hline C11 & 3.10 & Flat & 9 & R110 & Medium & Karoo/Shale & $2 \mathrm{WH}$ \\
\hline $\mathrm{C} 12$ & 17.00 & NE, Med slope & 11 & $\mathrm{R} 110$ & Medium & Karoo/Shale & $5 \mathrm{WEP}$ \\
\hline $\mathrm{S} 1$ & 1.80 & Flat & 10 & $\mathrm{R} 110$ & Low & Karoo & 4WEP \\
\hline $\mathrm{S} 2$ & 5.00 & Flat & 12 & R110 & Clear & Karoo/Shale & 4WEP \\
\hline S3 & 3.57 & Flat & 8 & $\mathrm{R} 110$ & Clear & Soft Karoo/Alluvial & $5 \mathrm{WEP}$ \\
\hline S4 & 5.99 & Flat & 8 & $\mathrm{R} 110$ & Clear & Karoo/Shale & $6 \mathrm{WEP}$ \\
\hline S5 & 3.40 & Flat & 11 & $\mathrm{R} 110$ & Clear & Karoo & $5 \mathrm{WEP}$ \\
\hline S6 & 7.20 & S, Med slope & 9 & $\mathrm{R} 110$ & Clear & Karoo/Shale & 4WEP \\
\hline S7 & 7.32 & Flat & 10 & Ramsey & Medium & Karoo/Shale & $5 \mathrm{WEP}$ \\
\hline S8 & 1.02 & Flat & 9 & R110 & $100 \%$ infected & Karoo & $2 \mathrm{WH}$ \\
\hline S9 & 3.74 & S, Steep slope & 11 & R110 & Low & Karoo & $5 \mathrm{WEP}$ \\
\hline $\mathrm{S} 10$ & 3.63 & S, Steep slope & 7 & R110 & Clear & Karoo & 7WEP \\
\hline S11 & 3.31 & Flat & 10 & R110 & Clear & Karoo & 4WEP \\
\hline
\end{tabular}

(1)Ha: Hectare;

(2)Orientations as follows, SE: South Eastern; NW: North Western; SW: South Western; NE: North Eastern; S: Southern; Med: Medium;

(3)Age from planting date until 2007;

(4)Rootstock abbreviations as follows, R99: Richter 99; R110: Richter 110; 101-14 MGT: 101-14 Millardet Et De Grasset ; US 8-7:

USVIT 8-7;

(5)Trellis systems abbreviated as follows, 4-7 WEP: 4-7 wire extended Perold system; 2 WH: double wire Hedge system;

(6)Not included in 2007

(Sigma Aldrich Chemie, Steinheim, Germany) dissolved in distilled water, ammonium sulphate (Merck) and epicatechin (Sigma) for the standard curve. Only the tannin portion of the protein precipitation method was performed; the colour measurements were excluded. The chemicals used in this precipitation method were glacial acetic acid (Saarchem, Merck), sodium chloride (Saarchem, Merck), potassium tartrate (Fluka, Sigma Aldrich), ethanol (Absolute Ethanol, Merck Chemicals PTY.Ltd.), triethanolamine (Fluka, Sigma Aldrich), Sodium dodecyl sulphate (Fluka, Sigma), iron chloride (Radchem), sodium sulphate (Merck), bovine serum albumin (Sigma) and catechin (Sigma) for the standard curve. All $\mathrm{pH}$ adjustments of the buffers for the BSA method were done using either 1 M HCL (32\% Hydrochloric acid, Merck) or $1 \mathrm{M}$ sodium hydroxide (Saarchem, Merck).

HPLC analyses for the determination of monomeric flavanols (Gallocatechin, Catechin, Proanthocyanin B1, Epicatechin, Proanthocyanin B2, Epicatechingallate), polymericflavanols(largepeakat $280 \mathrm{~nm}$ ), totalgrapeflavanols (sum of monomeric flavanols and polymeric flavanols), free anthocyanins (Delphinidin, Cyanidin, Petunidin, Peonidin and Malvidin as glucosides, acetoglucosides and coumaroyl glucosides), polymeric pigments (large peak at $520 \mathrm{~nm}$ ) and the total colour pigments (sum of free anthocyanins and polymeric pigments) were done using ethanol $(50 \% \mathrm{v} / \mathrm{v})$ extracted grape samples after $\mathrm{pH}$ adjustment (Table 2). It was analysed using an Agilent 1100 series RP-HPLC system (PLRPS-S 100Á $3 \mu \mathrm{m}, 150 \mathrm{x} 4.6 \mathrm{~mm}$ column) with a diode array detector (Peng et al., 2002).

Routine grape juice analyses were done after crushing of the grapes by hand. Sugar ( ${ }^{\circ}$ Brix) were measured using a refractometer (Atago, Pocket PAL-1), while the $\mathrm{pH}$ and TA were measured using a Metrohm titration system (Metrohm, Titrino 702 SM).

Topographical and data maps were created using ArcGIS 9.3.1 (ESRI). The maps were made by using the GPS points 
of each block and connecting that with the actual colour or phenolic data of that particular block. The concentration of a specific parameter was shown by different colours and the areas between the blocks were extrapolated between these GPS points.

All statistical calculations were done using Statistical software version 9 (Microsoft).

\section{RESULTS AND DISCUSSION}

Distribution of colour, phenolic content, ${ }^{\circ} \mathrm{B}, \mathrm{TA}$ and $\mathrm{pH}$ for all seasons and cultivars

The ${ }^{\circ} \mathrm{B}$ at which the grapes were picked ranged between $18.7-27.0^{\circ} \mathrm{B}$ (Table 3 ). This variability could influence the levels of phenolic compounds in the grapes, especially when samples of the lower ripeness ranges are compared to those in the higher sugar ranges. Of the 108 samples compared in this study only two samples were below $20.8^{\circ} \mathrm{B}$, both in 2007 , while 13 were above $25^{\circ} \mathrm{B}$ ( 2 blocks in 2007,3 blocks in 2008 and 8 blocks in 2009). When these outlying samples (removed from data reported) was removed, the average sugar level in the grapes during this study was $23.67^{\circ} \mathrm{B}$, with a range of $20.8-25.0^{\circ} \mathrm{B}$. The titratable acidity (TA) and $\mathrm{pH}$ were found to have a negative correlation of $0.45\left(\mathrm{r}^{2}\right.$ value $)$ indicating, as expected, that a higher $\mathrm{pH}$ led to lower TA values. The TA ranged between 3.45 and $8.38 \mathrm{~g} / \mathrm{L}$ for 2007 and 2009, while the $\mathrm{pH}$ ranged within 1.2 units over all the samples for 2007 to 2009 analysed in this study. Differences like these are normally related to different cultivars and the time of the season that maturity is reached (Bramley, 2005).

The monomeric flavanol concentrations for all 3 seasons and 4 cultivars ranged between $0.01-0.60 \mathrm{mg} / \mathrm{g}$ berry weights (Table 3). These results correlated with those of Mattivi et al., (2009), who found levels ranging between 0.06-0.32 $\mathrm{mg} / \mathrm{g}$ berry for Merlot, Cabernet Sauvignon and Shiraz grapes. In the study by Mattivi et al. (2009) the average monomeric flavanols levels were approximately $0.20 \mathrm{mg} / \mathrm{g}$. When comparing the monomeric flavanols in this study to the Mattivi et al., (2009) average, it was found that $73 \%$ of the Robertson data were below this average, despite the wider range.

Strong correlations were founds between polymeric flavanols (HPLC) and the total grape flavanols (HPLC) of the grape extracts $\left(r^{2}=1.00\right)$, hence only the latter will be discussed (Table 3). The total grape flavanols from the Robertson area ranged between 1.12-7.14 mg/g berry weight for the 2007-2009 harvest period with about 33\% of the blocks having values below $2 \mathrm{mg} / \mathrm{g}$. In the East of Australia Hanlin et al. (2009) found tannin concentrations (Total grape flavanols (HPLC)) to range between $0.7 \mathrm{mg} / \mathrm{g}$ berry when ripe to $7.1 \mathrm{mg} / \mathrm{g}$ berry when phenolically unripe. Ripe values were more or less between $0.7 \mathrm{mg} / \mathrm{g}$ and $1 \mathrm{mg} / \mathrm{g}$ for Cabernet and Shiraz grapes. Another study (Jensen et al., 2008) indicated levels of $0-4.5 \mathrm{mg} / \mathrm{g}$ berry, while Mattivi et al. (2009) reported average levels of about $0.6-3.3 \mathrm{mg} / \mathrm{g}$ berry. The total flavanols measured spectrophotometrically (total flavanols) had a much smaller range of $0.45-1.88 \mathrm{mg} / \mathrm{g}$ for the same samples from 2007-2009 and did not correlate with the HPLC readings $(\mathrm{r}=0.20(\mathrm{neg}))$. According to a study by Bramley (Bramley, 2005) on Australian red cultivars the range was $0.45-2.48 \mathrm{mg} / \mathrm{g}$, using the same measurement
TABLE 2

Description of parameters measured with HPLC for the grape and wine samples.

\begin{tabular}{|c|c|}
\hline Parameter & Range \\
\hline Monomeric flavanols & $\begin{array}{l}\text { Sum of phenolic compounds at } 280 \mathrm{~nm} \text {, } \\
\text { excluding the polymer }\end{array}$ \\
\hline Polymeric flavanols & Large peak at $280 \mathrm{~nm}$ \\
\hline Total grape flavanols & Sum of phenolic compounds at $280 \mathrm{~nm}$ \\
\hline Free anthocyanins & $\begin{array}{l}\text { Sum of pigments measured at } 520 \mathrm{~nm} \text {, } \\
\text { excluding the polymer }\end{array}$ \\
\hline Polymeric pigments & Large peak at $520 \mathrm{~nm}$ \\
\hline Total colour pigments & Sum of colour pigments at $520 \mathrm{~nm}$ \\
\hline
\end{tabular}

TABLE 3

Ranges, averages and standard errors of Colour and phenolic compounds, sugar concentration $\left({ }^{\circ} \mathrm{B}\right)$ and total acidity (TA) of all the vineyards selected for this survey of Robertson grapes for all three seasons.

\begin{tabular}{|c|c|c|}
\hline Parameter $(n=108)^{1}$ & Range & Mean \pm SD $^{6}$ \\
\hline Monomeric flavanols & $0.01-0.60$ & $0.17 \pm 0.07$ \\
\hline Polymeric flavanols & $1.04-7.03$ & $2.96 \pm 0.12$ \\
\hline Total grape flavanols & $1.12-7.14$ & $3.13 \pm 0.12$ \\
\hline Free anthocyanins & $0.12-1.75$ & $0.67 \pm 0.03$ \\
\hline Polymeric pigments & $0.00-0.33$ & $0.08 \pm 0.00$ \\
\hline Total colour pigments & $0.19-1.99$ & $0.75 \pm 0.03$ \\
\hline Anthocyanin ${ }^{2}$ & $0.39-1.95$ & $0.85 \pm 0.05$ \\
\hline Total phenols ${ }^{3}$ & $0.45-1.88$ & $1.20 \pm 0.08$ \\
\hline Tannin & $0.22-8.18$ & $2.24 \pm 0.09$ \\
\hline${ }^{\circ} \mathrm{B}^{4}$ & $18.7-27.0$ & $23.8 \pm 0.21$ \\
\hline $\mathrm{pH}$ & $3.23-4.40$ & $3.69 \pm 0.02$ \\
\hline $\mathrm{TA}^{5}$ & $3.45-8.38$ & $5.21 \pm 0.45$ \\
\hline
\end{tabular}

(1)All data are expressed in $\mathrm{mg} / \mathrm{g}$ berry weight except for

Anthocyanin, Total phenols, ${ }^{\circ} \mathrm{B}, \mathrm{pH}$ and TA;

(2)Anthocyanin in $\mathrm{mg} / \mathrm{g}$ malvidin-3-glucoside units

(3)Total phenols in $\mathrm{mg} / \mathrm{g}$ absorbance units

(4)Degrees Brix;

(5)g/L; expressed as tartaric acid

(6)SD: standard deviation

technique.

The total colour pigments and free anthocyanins were closely correlated $(\mathrm{r}=0.99)$ and only the free anthocyanins will therefore be discussed. The levels for 2007-2009 were between $0.12-1.75 \mathrm{mg} / \mathrm{g}$ berry weight, which is in the same range as the $0.6-0.9 \mathrm{mg} / \mathrm{g}$ berry weight (average 0.75 $\mathrm{mg} / \mathrm{g}$ ) found by Romero-Cascales et al. (2005) in Cabernet, Shiraz and Merlot from South Eastern Spain. Another study (Segade et al., 2008) reported the anthocyanin content to be between 0.16 and $1.45 \mathrm{mg} / \mathrm{g}$ berry weight (average 0.81 $\mathrm{mg} / \mathrm{g}$ ) in their quest to understand the assessment of phenolic ripeness. The average for this study was $0.67 \mathrm{mg} / \mathrm{g}$ which was less than that reported by the above-mentioned studies. The anthocyanin concentration as measured using the Iland method (Iland, 2000) did not correlate well with the HPLC values $(r=0.27)$, but was found to be in a similar range than the HPLC values $(0.39-1.95 \mathrm{mg} / \mathrm{g}$ berry weight). In another study on red grape varieties the anthocyanin concentration measured by the same technique varied between $0.58-3.71$ $\mathrm{mg} / \mathrm{g}$ berry weight (Bramley, 2005), clearly indicating the higher colour found in these grapes. 
Seasonal differences in the distribution of colour, phenolic compounds, ${ }^{\circ} \mathrm{B}$, TA and $\mathrm{pH}$

The distribution of the colour and phenolic content of the selected vineyards were greatly influenced by season. After multivariate analyses of all the parameters measured, it was found that during 2007, the data points were distributed over a larger range than what was found for the 2008 and 2009 seasons (Fig. 3). This variation was driven by polymeric pigments, polymeric flavanols and total flavanols (all by HPLC analyses). To illustrate this point the 2007 polymeric flavanol range were $1.23-7.03 \mathrm{mg} / \mathrm{g}$ while the ranges were $1.31-5.05 \mathrm{mg} / \mathrm{g}$ and $1.04-3.47 \mathrm{mg} / \mathrm{g}$ in 2008 and 2009 respectively (Table 4). Similar trends were seen with regards to the total grape flavanols and the polymeric pigments.

Parameters that were correlated for the perspective of seasonality included free anthocyanins and total grape pigments, polymeric and total grape flavanols. An inverse correlation were found between $\mathrm{pH}$ and total acidity.

Significant differences were found in each parameter related to seasonal influences. The polymeric flavanols, total grape flavanols, free anthocyanins and total colour pigments differed significantly between the three seasons, with 2007 recording the highest concentration. In general, polymeric and total flavanols were higher in 2008 than 2009, while free anthocyanins and total grape pigments showed an opposite tendency.

Polymeric pigments and $\mathrm{pH}$ were significantly higher in 2007 than in the other two years, while the total phenols (Iland method) were significantly lower in 2007. Anthocyanins (determined by the Iland method) and sugar content showed a significant difference between 2007 and 2009, with 2008 falling somewhere in between. The anthocyanin level in 2007 showed an average of $0.74 \mathrm{mg} / \mathrm{g}$ berry weight versus the $0.97 \mathrm{mg} / \mathrm{g}$ observed in 2009. In 2007 the sugar concentration was significantly lower $\left(23.4{ }^{\circ} \mathrm{B}\right)$ than in $2009\left(24.3^{\circ} \mathrm{B}\right)$. The removal of three outlying blocks sampled in 2007 (Blocks P6, S1 and S8) shifted this average to $23.7^{\circ} \mathrm{B}$, which was no longer significantly different from the other seasons. However, it should be kept in mind that degree brix is linked to the sugar per berry and the volume of the berry, which should be kept in mind when the seasonal influence on anthocyanin level is investigated (Wang et al., 2003). In another study on production norms of Robertson grape cultivars, the grapes were picked each year at $23{ }^{\circ} \mathrm{B}$, but the number of days from veraison to that point were also recorded. It was found that a specific block reached $23{ }^{\circ} \mathrm{B}$ faster than others due to the climatic influence (Van Schalkwyk \& De Villiers, 1999). Some studies found that an increase in Brix is often due to a decrease in berry volume, which is not directly related to the evolution of the berry aromatic sequence but to the site and the vine water status (Deloire, 2011).

Monomeric flavanols and total acidity did not differ significantly for 2007 and 2009, but significantly from 2008 levels. The free anthocyanins were lower during 2008 (0.14 $\mathrm{mg} / \mathrm{g}$ ) than for 2007 and 2009 (both $0.20 \mathrm{mg} / \mathrm{g}$ average). In the case of total acidity the highest acidity levels were found during 2008 (average $5.56 \mathrm{~g} / \mathrm{L}$ ) compared to the $5.28 \mathrm{~g} / \mathrm{L}$ of 2007 and the $4.95 \mathrm{~g} / \mathrm{L}$ of 2009.

The use of data mapping presents results more visually (Table 5). Since the data were not collected in a grid-like manner covering the whole Robertson grape growing area, there are some limitations in the interpretation of the data. The coloured areas in between the data points (blocks) are just a function of the average values of the components measured at the actual geographical positions of the blocks evaluated, therefore extrapolated data. As mentioned above, the free anthocyanins and the total colour pigments correlated for the seasonal data, the same is true for the polymeric and total grape flavanols. Only one of each of these correlating parameters was therefore illustrated using the GPS points. The total colour pigments and total grape flavanols were

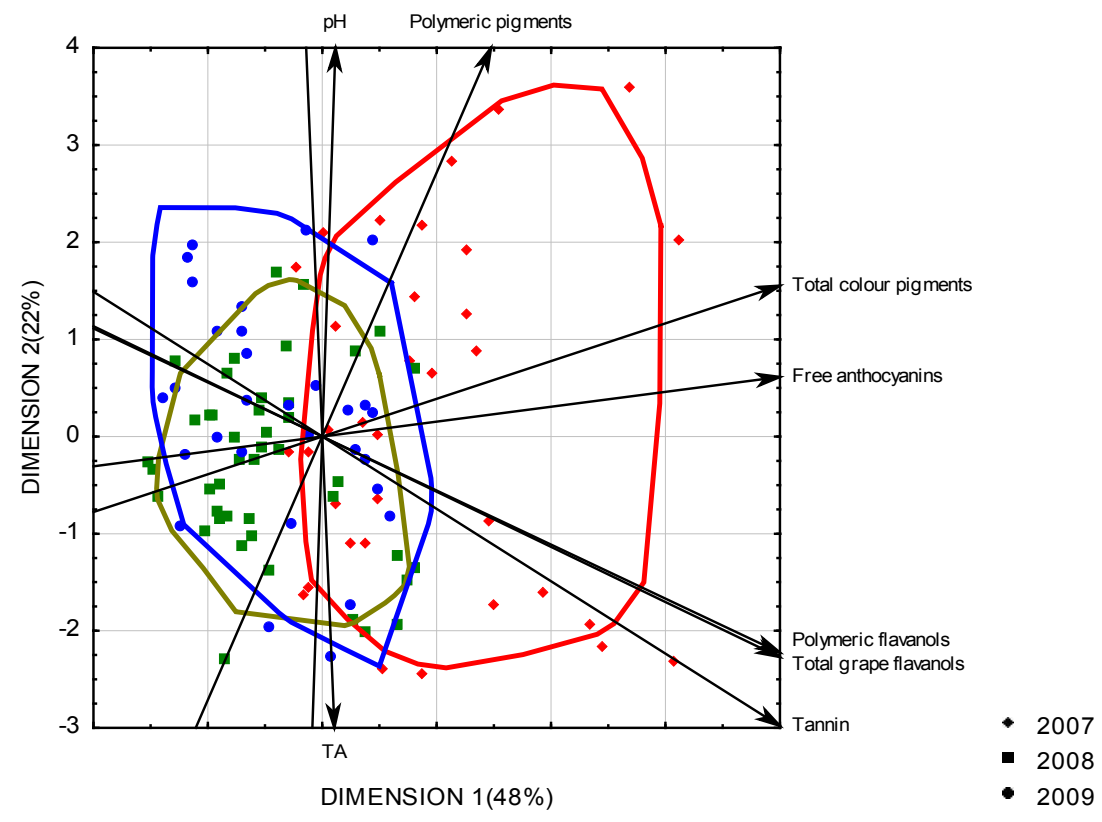

FIGURE 3

Distribution of grape berry parameters during the 2007-2009 harvest seasons. Lines drawn around data points indicate a $95 \%$ confidence level, points outside these lines are deemed outliers for the specific season. 
TABLE 4

Ranges, averages and standard errors of colour and phenolic compounds, sugar concentration $\left({ }^{\circ} \mathrm{B}\right), \mathrm{pH}$ and total acidity (TA) of Pinotage, Merlot Cabernet Sauvignon and Shiraz grapes during the 2007, 2008 and 2009 harvests in the Robertson wine region. Different letters in the same row indicate significance at $\mathrm{p}<0.5$.

\begin{tabular}{|c|c|c|c|c|c|c|}
\hline \multirow[b]{2}{*}{ Parameter $^{1}$} & \multicolumn{2}{|c|}{2007} & \multicolumn{2}{|c|}{2008} & \multicolumn{2}{|c|}{2009} \\
\hline & Range & Means \pm SD $^{6}$ & Range & Means \pm SD & Range & Means \pm SD \\
\hline Monomeric flavanols & $0.03-0.40$ & $0.20^{\mathrm{a}} \pm 0.02$ & $0.01-0.32$ & $0.14^{b} \pm 0.01$ & $0.02-0.60$ & $0.20^{\mathrm{a}} \pm 0.02$ \\
\hline Polymeric flavanols & $1.23-7.03$ & $4.08^{\mathrm{a}} \pm 0.16$ & $1.31-5.05$ & $2.84^{b} \pm 0.14$ & $1.04-3.47$ & $2.11^{c} \pm 0.17$ \\
\hline Total grape flavanols & $1.33-7.14$ & $4.28^{\mathrm{a}} \pm 0.17$ & $1.44-5.24$ & $2.98^{b} \pm 0.14$ & $1.12-3.99$ & $2.30^{c} \pm 0.18$ \\
\hline Free anthocyanins & $0.41-1.75$ & $0.87^{\mathrm{a}} \pm 0.04$ & $0.12-1.15$ & $0.46^{b} \pm 0.04$ & $0.33-1.25$ & $0.75^{\mathrm{c}} \pm 0.04$ \\
\hline Polymeric pigments & $0.00-0.33$ & $0.09^{\mathrm{b}} \pm 0.01$ & $0.04-0.17$ & $0.08^{\mathrm{a}} \pm 0.01$ & $0.04-0.12$ & $0.07^{\mathrm{a}} \pm 0.01$ \\
\hline Total colour pigments & $0.48-1.99$ & $0.96^{\mathrm{a}} \pm 0.05$ & $0.19-1.23$ & $0.54^{b} \pm 0.04$ & $0.40-1.33$ & $0.82^{\mathrm{c}} \pm 0.05$ \\
\hline Anthocyanin ${ }^{2}$ & $0.40-1.22$ & $0.74^{\mathrm{a}} \pm 0.05$ & $0.39-1.44$ & $0.86^{\mathrm{ab}} \pm 0.04$ & $0.50-1.95$ & $0.97^{\mathrm{b}} \pm 0.05$ \\
\hline Total phenols ${ }^{3}$ & $0.45-1.35$ & $0.98^{b} \pm 0.08$ & $0.77-1.81$ & $1.31^{\mathrm{a}} \pm 0.07$ & $0.48-1.88$ & $1.28^{\mathrm{a}} \pm 0.09$ \\
\hline Tannin & $1.78-8.88$ & $4.57 \pm 0.14$ & $0.22-2.03$ & $1.20 \pm 0.12$ & $0.50-2.97$ & $1.44 \pm 0.14$ \\
\hline${ }^{\circ} B^{4}$ & $18.7-26.7$ & $23.4^{\mathrm{a}} \pm 0.22$ & $21.8-26.3$ & $23.8^{\mathrm{ab}} \pm 0.18$ & $20.8-27.0$ & $24.3^{b} \pm 0.22$ \\
\hline $\mathrm{pH}$ & $3.30-4.40$ & $3.72^{\mathrm{b}} \pm 0.02$ & $3.37-4.11$ & $3.64^{a} \pm 0.02$ & $3.23-4.05$ & $3.63^{\mathrm{a}} \pm 0.03$ \\
\hline $\mathrm{TA}^{5}$ & $3.45-6.71$ & $5.28^{\mathrm{a}} \pm 0.16$ & $3.48-8.38$ & $5.56^{\mathrm{b}} \pm 0.13$ & $3.60-7.27$ & $4.95^{\mathrm{a}} \pm 0.16$ \\
\hline
\end{tabular}

(1)All data are expressed in $\mathrm{mg} / \mathrm{g}$ berry weight except for Anthocyanin, Total phenols, ${ }^{\circ} \mathrm{B}, \mathrm{pH}$ and TA;

(2)Anthocyanin in $\mathrm{mg} / \mathrm{g}$ malvidin-3-glucoside units;

(3) Total phenols in $\mathrm{mg} / \mathrm{g}$ absorbance units;

(4)Degrees Brix

(5) $\mathrm{g} / \mathrm{L}$;

(6)SD: standard deviation

found to be significantly different for the three seasons (according to Table 4). This is visible from the data maps overlaying the topographical maps of the Robertson area. During 2007 and 2009 the average total colour pigments ( 0.96 and $0.82 \mathrm{mg} / \mathrm{g}$ berries respectively) were higher than in $2008(0.54 \mathrm{mg} / \mathrm{g})$. Small zones of high colour pigment levels are visible from the 2007 and 2009 maps, whilst a more moderated spread of total colour pigments can be seen in 2007.

The average total grape flavanols were higher in 2007 $(4.28 \mathrm{mg} / \mathrm{g}$ berry) than in $2008(2.98 \mathrm{mg} / \mathrm{g})$ and $2009(2.30$ $\mathrm{mg} / \mathrm{g}$ ). The latter two seasons were both lower on average than 2007 but still statistically significantly different. The data ranges were from widest to closest 2007>2008>2009. Lower values of total grape flavanols tend to be linked to phenolically riper grapes (Hanlin et al., 2009). From the GPS maps, 2007 had less dark blue areas (low total grape flavanols) than the other seasons, while the statistically significant difference between the seasons is very visible.

The areas where high sugar levels were experienced can clearly be defined from the lower brix regions. For instance, it was found that the brix in the 2007 season was significantly different from that of the 2009 harvest season (Table 6). It is clear from the visual data that in 2007 higher brix were reached in the centre (close to town) areas of the region that was covered by this survey, while in 2009 the higher brix levels were found on the outskirts of the region. With regards to $\mathrm{pH}$, the levels was found to be different between 2007 and the other two seasons. From the spatial data mapping, it appears that 2007 and 2009 are similar and different to 2008, but from the statistical data 2008 and 2009 were different with a lower average than 2007 . The average TA in 2008 was significantly different from the other seasons. In 2008 the TA were at moderate levels throughout the region, while

in the other two seasons there were specific zones with high TA or low TA values.

Mapping of data over a region like Robertson would have been more useful if more data points could have been selected. This should be done by establishing a virtual grid over the area and sampling vineyards in every square kilometre for a complete picture. This would provide the area with valuable information to pin point niche areas of high colour or tannin, or to identify problem areas, or special $\mathrm{pH}$, TA zones.

\section{Cultivar differences in the distribution of colour and phenolic compounds}

The distribution of colour and phenolic compounds, as well as acidity ( $\mathrm{pH}$ and TA), of the different cultivars displayed great variability (Fig. 4). A positive correlation were found between the levels of polymeric flavanols, total grape flavanols and tannins as was the case for the seasonal data. The positive correlation between the polymeric and total grape flavanols were due to the fact that very little monomeric flavanols were measured and therefore the total grape flavanols reflects the polymeric flavanols in the grapes. The tannins which were precipitated by BSA (BSA, 2007 data not included in subsequent calculations) correlated with the HPLC results since more or less similar amounts of flavanols were measured with these two methods. In other studies, positive correlations between BSA grape tannins and total grape flavanols as measured by the HPLC $(50 \%$ ethanol grape extracts) were also observed (Mercurio \& Smith, 2008). The same was found for the free anthocyanins and total grape pigments, while $\mathrm{pH}$ and TA showed a high negative correlation to each other. The Polymeric pigments did not correlate with any of the other colour measurements and the levels of these compounds present in grapes are normally extremely low. No significant differences were found between the average levels of anthocyanins and total phenols as measured using Iland's method (Iland et al., 2000) and will therefore not be mentioned further in 
TABLE 5

Geographical maps of the Robertson region overlaid with the actual total colour pigment (A) and total grape flavanols (B) data as found for the 2007, 2008 and 2009 harvests.

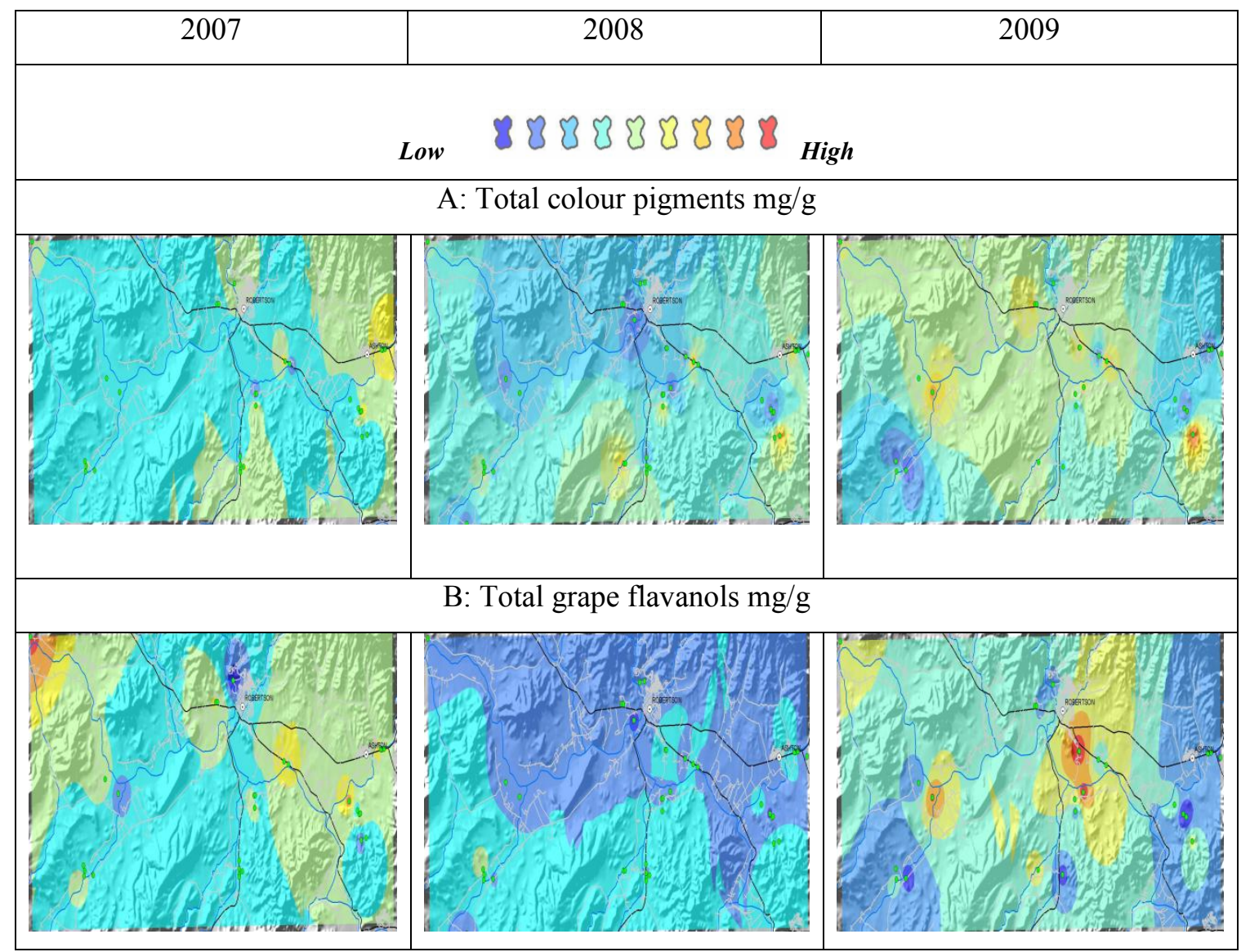

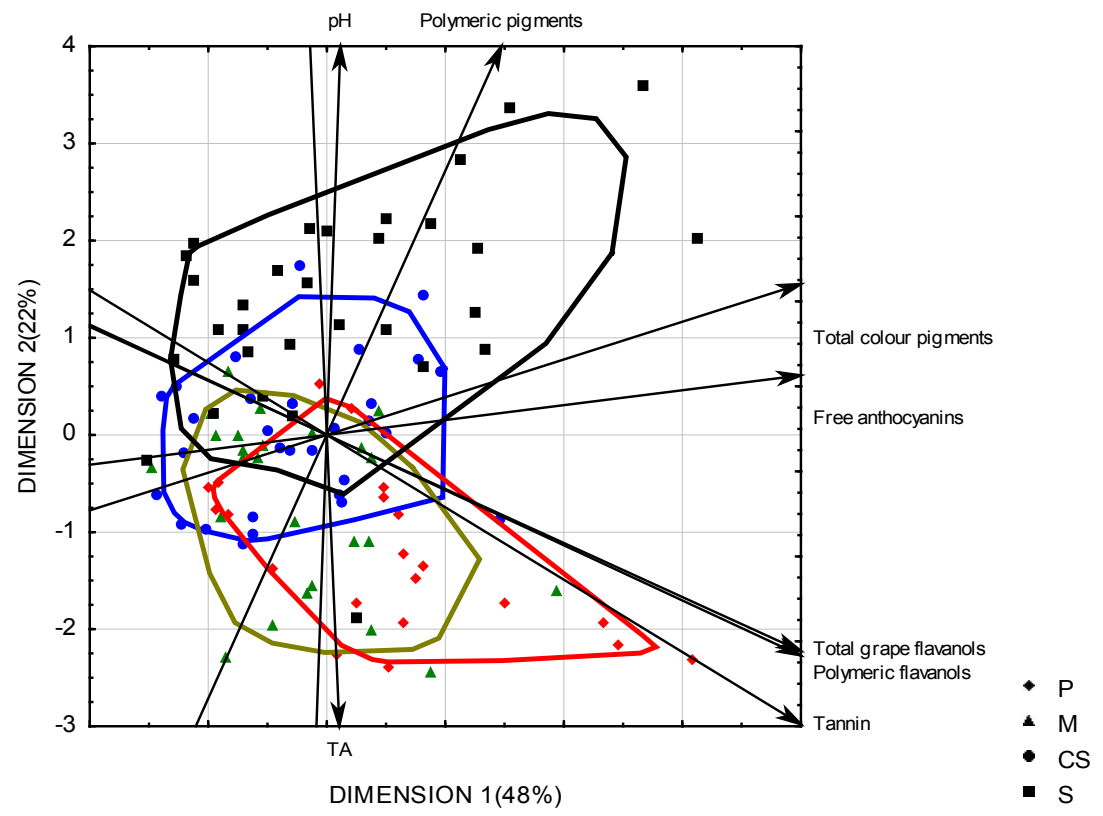

FIGURE 4

The distribution of grape berry measurements during the 2007-2009 harvest seasons, separated for each cultivar. P: Pinotage;

M: Merlot; CS: Cabernet Sauvignon; S: Shiraz. Lines drawn around data points indicate a 95\% confidence level, points outside these lines are deemed outliers for the specific cultivars. 2007 Tannin data was not included in calculations. 
TABLE 6

Geographical maps of the Robertson region overlaid with the actual Brix (A) pH (B) and titratable acidity (TA) (C) data as found for the 2007, 2008 and 2009 harvests.

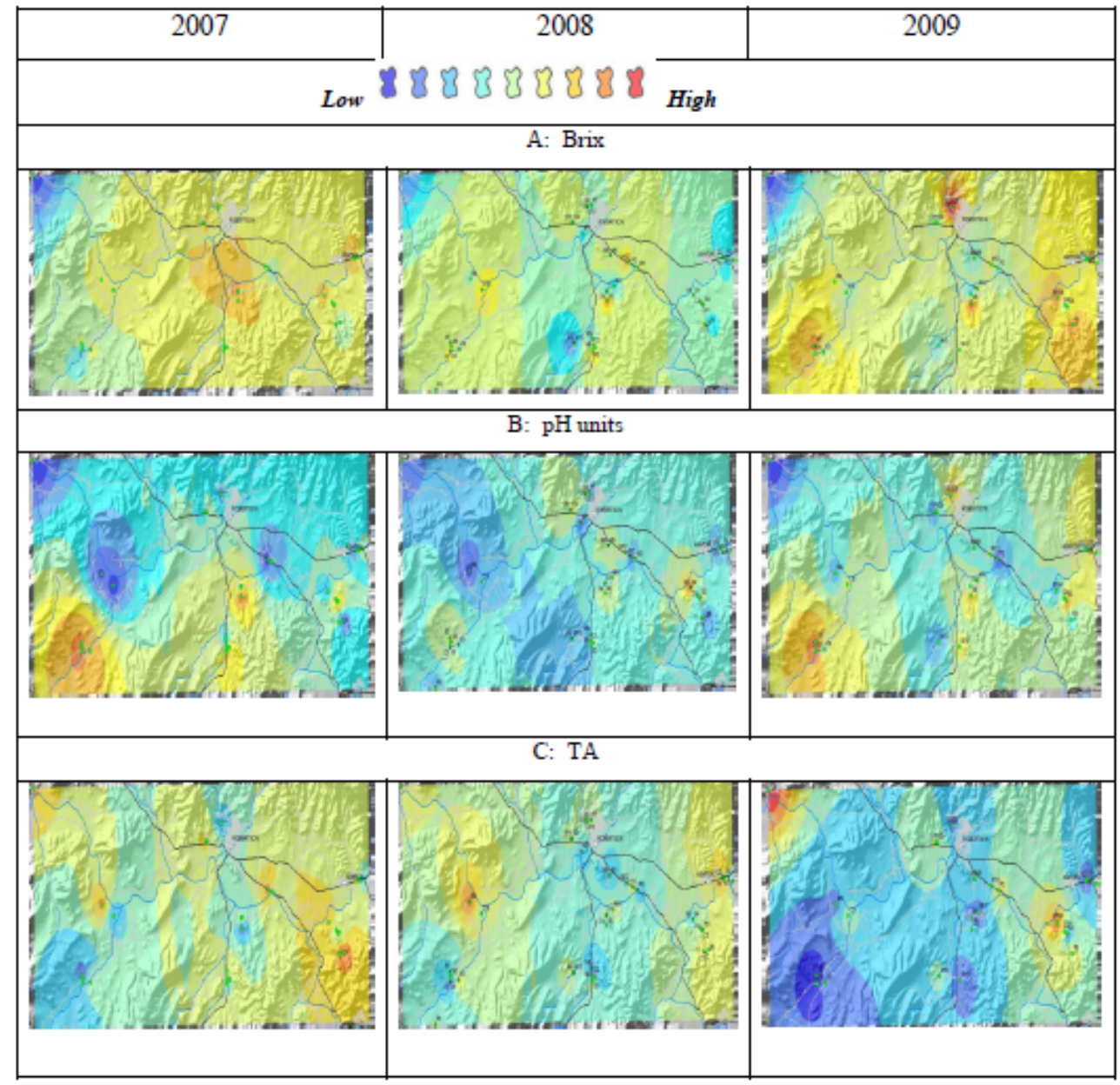

discussion about cultivar differences. Shiraz had a much wider distribution of data points than the other cultivars for the combined three seasons data. This distribution was driven mostly by polymeric pigments, but in some instances also by $\mathrm{pH}$. Apart from inherent cultivar differences this could also have been a function of the later ripening stages of Shiraz grapes when compared to the other cultivars. A wider distribution in Pinotage was driven by tannins, polymeric flavanols, total grape flavanols and TA being higher. In this case, when disregarding inherent cultivar characteristics, it could be related to the fact that Pinotage is normally the first red grapes that are picked in a winemaking season. The Merlot, Cabernet Sauvignon and Pinotage blocks recorded a much tighter data range than Shiraz. The data points (blocks) that are pulling the data outwards are all from the 2007 season and therefore also related to seasonal variance.

Pinotage had the highest average polymeric phenol (3.68 $\mathrm{mg} / \mathrm{g})$, total grape flavanols $(3.83 \mathrm{mg} / \mathrm{g})$, free anthocyanin $(0.88 \mathrm{mg} / \mathrm{g})$, total colour pigments $(0.96 \mathrm{mg} / \mathrm{g})$, tannin $(2.98 \mathrm{mg} / \mathrm{g})$ and total acidity $(6.04 \mathrm{~g} / \mathrm{L})$ content of all four cultivars investigated (Table 7). In a study that compared the malvidin-3-glucoside and procyanidin (B1) content of Cabernet Sauvignon, Shiraz and Pinotage it was found that the latter had much higher levels of these components (Rossouw \& Marais, 2004). Pinotage were harvested at the lowest average sugar levels $\left(23.2^{\circ} \mathrm{B}\right)$ and $\mathrm{pH}$ of 3.44 of all four cultivars.

Merlot was found to be lowest in colour components of the four cultivars. It had average levels of $0.57,0.05$ and 0.62 $\mathrm{mg} / \mathrm{g}$ berry weight for free anthocyanins, polymeric pigments and total colour pigments respectively. This was also found in another study that compared the free anthocyanin levels between other red cultivars and Merlot, where the latter was found to have the lowest content at $0.58 \mathrm{mg} / \mathrm{g}$ (RomeroCascales et al., 2005). However, the Merlot blocks had the highest average monomeric flavanol content at $0.24 \mathrm{mg} / \mathrm{g}$ berry weight compared to the other three cultivars with average levels ranging between $0.12-0.20 \mathrm{mg} / \mathrm{g}$ (Table 7). For the other components Merlot had intermediate levels in comparison with the other cultivars. Cabernet Sauvignon was found to have intermediate levels compared to the other cultivars for all the components measured during this study.

Shiraz had the highest average levels of $\mathrm{pH}(3.95),{ }^{\circ} \mathrm{B}$ (24.3) and polymeric pigments $(0.11 \mathrm{mg} / \mathrm{g})$. For the $\mathrm{pH}$ and Brix these results were the inverse of those found for Pinotage (Table 7). The lowest tannin $(1.89 \mathrm{mg} / \mathrm{g})$ and titratable acidity $(4.60 \mathrm{~g} / \mathrm{L})$ were also found in the Shiraz blocks. In another study that compared the tannin content of Cabernet Sauvignon, Shiraz and Merlot it was found that Shiraz and Merlot had low tannin content $(1.3 \mathrm{mg} / \mathrm{g}$ and 1.0 $\mathrm{mg} / \mathrm{g}$ respectively), while the Cabernet Sauvignon had the highest tannin level at $2.2 \mathrm{mg} / \mathrm{g}$ (Romero-Cascales et al., 
2005). Shiraz ripened at the end of the harvesting season and were marked by high pH's and lower acidity.

\section{Blocks that was found to be outliers from the data set due to seasonal or cultivar influence}

After statistical analyses of the data set, including all parameters over all three seasons and for all the cultivars, blocks that were found to be outliers from the data set were identified (95\% confidence level) (Table 8$)$. When the data was analysed from the perspective of seasonal influence there were 11 blocks that did not fit the data set at a $95 \%$ confidence level in 2007, 9 blocks in 2008 and 4 blocks in 2009. It is most likely that the environmental factors varied more in 2007 when compared to 2008 and 2009. This was indeed visible in the temperature data (Fig. 5, next section) especially during the crucial ripening months of January to April. Site specifics could also play a major role especially in cases where the same block was found to be an outlier for more than one season. For instance Pinotage 2 and 5, Merlot 6 and Shiraz 4 and 5 were such examples, identified as outliers over more than two seasons. The two Pinotage blocks (2 and 5) seem to fit the average site specifics of all 9 Pinotages selected for this survey: Average size, one flat and one sloped, same age, different rootstocks, clear and low virus infection and Karoo soils. According to the parameters analysed, these Pinotage blocks stood out due to extreme tannin and acid levels in comparison with the other blocks in 2007. Merlot 6 was the only Merlot planted on a USVIT 8-7 rootstock, one of the youngest and largest blocks of Merlot analysed during the study. These distinguishing site specifics are possible factors that could have led to higher total acidity and tannin content compared to other blocks. The effect of rootstock on grape composition is not well known but is probably related to rootstock vigor and therefore influences the growth and canopy exposure (Jackson \& Lombard, 1993). Rootstocks promoting more vigorous growth yielded fruit with higher nitrogen, acidity, tannin and $\mathrm{K}$ levels and lower $\mathrm{pH}$ (Ough et al., 1968), while the devigorating rootstocks produced higher wine scores (McCarthy \& Cirami, 1990). The rootstock is mostly influenced by the soil water status and therefore vine water status. This ultimately influences the vigour and berry growth, ripening and composition (Ollat et al., 2002; Ojeda et al., 2001). Shiraz 4 and 5 were higher in polymeric pigments and $\mathrm{pH}$ than the rest of the groups. They differed in size, age and soil type but were similar in orientation, rootstock and virus infection level. High polymeric pigments and $\mathrm{pH}$ could indicate that the grapes were harvested last or very late in the season and was overripe. For both blocks the degrees brix ranged between 22 and 27 over the three years, while the average sugar level for Shiraz throughout the study was approximately $24^{\circ} \mathrm{B}$.

When the outliers were determined from a cultivar perspective it was found that 4/9,5/12,5/12 and 4/12 of the Pinotage, Merlot, Cabernet Sauvignon and Shiraz blocks respectively fell outside the $95 \%$ confidence interval for all parameters measured in this study.

More specifically, Pinotage 3 and 4, Merlot 6, Cabernet 5 and 8 as well as Shiraz 3 and 5 fell outside the 95\% confidence level more than once. The Pinotage blocks again showed this tendency due to its high tannins and acidity, while Merlot 6 had a unique rootstock. Cabernet Sauvignon 8 was the second largest block sampled during this survey and was one of two blocks sampled that were planted on a steep slope and had a medium virus infection. Cabernet 8 was also the only Cabernet Sauvignon planted on a Varia rootstock, further distinguishing it from the rest. This block stood out due to very low levels of total colour pigments and free anthocyanins both in 2008 and 2009. Vines freed from major viruses are healthier and give higher yields and improved wine quality (Becker, 1985), therefore infected vines could be connected to restricted sugar and colour development in grape berries.

Other unique blocks, not featuring as outliers, were found in this data set. With regards to block size, Cabernet Sauvignon 10 and 12 were also $>10$ ha in size and did not appear as outliers in any instance. Age plays an important role in the overall yield and quality of grapes. Block C3 was 17 years old versus the other blocks which were between 8-13 years old, and it never was reported as an outlier. Blocks M11, C3 and S8 were 100\% visually infected with leaf roll virus, which impacts the colour developments of such blocks negatively. M11 stood out in 2009 due to higher free anthocyanins and total colour pigments than the other blocks, completely opposite to what should be expected. Trellis systems are important for aeration and ensure proper bud and bunch exposure (May \& Antcliff, 1963). Of the selected blocks for this study 3 blocks were 2 wired hedge systems for lower vigour vines, but they were never outliers. The same goes for S10 on a 7 wire extended Perold trellis system, S7 that was the only Shiraz on a Ramsey rootstock and P6 that was the only Pinotage on a Varia rootstock. The vigour of the vines is mostly impacted by irrigation practices which seem to be the case for these vineyards. Vine water status and especially the creation of water deficit periods at pivotal times in the ripening stage is key to colour and phenolic development of grape berries as well as overall grape and wine quality (Myburgh, 2006; Bindon et al., 2011).

\section{Influence of environment and site on colour and phenolic content}

To discuss the colour and phenolic content and the distribution thereof during the 2007-2009 harvesting period properly, the influence of the environment and site specific conditions should also be taken into account (Table 9).

Various environmental factors could influence the biosynthesis of flavonoids in grapes, such as light, temperature, altitude, soil type, water, nutritional status, microbial interactions, pathogenesis, wounding, defoliation, plant growth regulators as well as various developmental processes (Downey et al., 2005). Site/Vine specific data were obtained from the Robertson vineyards that were selected for this study and statistically analysed to determine if any of these factors correlate in some way with the levels of the parameters measured. It was found that there were a significant negative correlation between the level of virus infection (leaf roll) versus the colour of grapes (Free anthocyanins, $\mathrm{p}<0.04$; Total colour pigments, $\mathrm{p}<0.03$ ). This means that with an increased intensity of virus infection the actual colour of the grapes at harvest decreased. The orientation, soil and trellis systems were divided into 2 main 
groups each to create large enough groups for improved statistical analyses (Table 9). The results showed no significant differences between any of these groups (flat vs. slope; Karoo vs. Karoo/shale; 4WEP vs. 5WEP), but rather that trends could be observed in some instances. For example a higher average level of all parameters measured was detected in the Karoo/Shale soils when compared to the levels found in the Karoo soils. Other studies found that soil characteristics can affect grape quality dramatically; especially fertile soils that can cause higher yields (Winkler et al., 1974). Other studies that tested the effect of different soils on anthocyanin content of grapes did not find significant influences (Yokotsuka et al., 1999). However, it must also be kept in mind that these results are also impacted by the small datasets analysed.

The temperature for the Robertson area was constantly monitored using permanent weather stations throughout the area. The data showed that during 2008 the average maximum temperature $\left(28.4{ }^{\circ} \mathrm{C}\right)$ was lower than during 2007 and 2009 (29.4 and $29.1^{\circ} \mathrm{C}$ ) (Fig. 5). The variability in maximum temperature was higher during 2007 and 2008 (standard deviation (SD) of \pm 2.2 and $\pm 1.9^{\circ} \mathrm{C}$ respectively) than what was experienced during $2009\left( \pm 1.6{ }^{\circ} \mathrm{C}\right.$ SD). Another important observation was that the data from the

\section{TABLE 7}

The ranges, average levels and standard error of colour and phenolic compounds due to cultivar difference measured over 3 harvest seasons (2007-2009) in Pinotage, Merlot, Cabernet Sauvignon and Shiraz grapes from the Robertson wine region.

\begin{tabular}{|c|c|c|c|c|c|c|c|c|}
\hline \multirow[b]{2}{*}{ Compound/Parameter ${ }^{1}$} & \multicolumn{2}{|c|}{ Pinotage } & \multicolumn{2}{|c|}{ Merlot } & \multicolumn{2}{|c|}{ Cabernet Sauvignon } & \multicolumn{2}{|c|}{ Shiraz } \\
\hline & Range & Average/SD ${ }^{6 *}$ & Range & Average/SD* & Range & Average/SD* & Range & Average/SD* \\
\hline Monomeric flavanols & $0.01-0.33$ & $0.16^{\mathrm{ab}} \pm 0.02$ & $0.08-0.60$ & $0.24^{\mathrm{c}} \pm 0.02$ & $0.05-0.56$ & $0.20^{\mathrm{ac}} \pm 0.02$ & $0.02-0.35$ & $0.12^{\mathrm{b}} \pm 0.02$ \\
\hline Polymeric flavanols & $1.78-7.03$ & $3.68^{\mathrm{a}} \pm 0.20$ & $1.43-6.28$ & $3.14^{\mathrm{ab}} \pm 0.19$ & $1.04-4.02$ & $2.43^{\mathrm{b}} \pm 0.17$ & $1.19-5.05$ & $2.79^{\mathrm{b}} \pm 0.17$ \\
\hline Total grape flavanols & $1.95-7.14$ & $3.83^{\mathrm{a}} \pm 0.21$ & $1.60-6.52$ & $3.39^{\mathrm{ab}} \pm 0.19$ & $1.12-4.26$ & $2.63^{\mathrm{c}} \pm 0.18$ & $1.21-5.24$ & $2.91^{\mathrm{bc}} \pm 0.17$ \\
\hline Free anthocyanins & $0.31-1.52$ & $0.88^{\mathrm{c}} \pm 0.05$ & $0.15-0.90$ & $0.57^{\mathrm{a}} \pm 0.05$ & $0.18-1.04$ & $0.62^{\mathrm{ab}} \pm 0.05$ & $0.12-1.35$ & $0.69^{b} \pm 0.04$ \\
\hline Polymeric pigments & $0.05-0.14$ & $0.08^{\mathrm{a}} \pm 0.01$ & $0.00-0.11$ & $0.05^{\mathrm{b}} \pm 0.01$ & $0.03-0.14$ & $0.07^{\mathrm{ab}} \pm 0.01$ & $0.06-0.20$ & $0.11^{\mathrm{c}} \pm 0.01$ \\
\hline Total colour pigments & $0.36-1.63$ & $0.96^{\mathrm{a}} \pm 0.06$ & $0.20-0.94$ & $0.62^{\mathrm{b}} \pm 0.05$ & $0.22-1.13$ & $0.69^{\mathrm{b}} \pm 0.05$ & $0.19-1.42$ & $0.81^{\mathrm{a}} \pm 0.05$ \\
\hline Anthocyanins ${ }^{2}$ & $0.61-1.73$ & $0.89 \pm 0.06$ & $0.39-1.95$ & $0.83 \pm 0.06$ & $0.60-1.90$ & $0.87 \pm 0.05$ & $0.44-1.93$ & $0.84 \pm 0.05$ \\
\hline Total phenols ${ }^{2}$ & $0.48-1.88$ & $1.23 \pm 0.10$ & $0.56-1.55$ & $1.20 \pm 0.10$ & $0.75-1.77$ & $1.26 \pm 0.09$ & $0.45-1.81$ & $1.31 \pm 0.08$ \\
\hline Tannin & $0.77-8.18$ & $2.98^{\mathrm{a}} \pm 0.17$ & $0.62-6.89$ & $2.76^{\mathrm{ab}} \pm 0.16$ & $0.50-5.32$ & $1.99^{\mathrm{b}} \pm 0.14$ & $0.22-4.82$ & $1.89^{\mathrm{b}} \pm 0.14$ \\
\hline${ }^{\circ} \mathrm{B}^{3}$ & $18.7-26.7$ & $23.2^{\mathrm{a}} \pm 0.27$ & $21.9-26.1$ & $23.8^{\mathrm{ab}} \pm 0.25$ & $21.2-25.6$ & $24.0^{\mathrm{b}} \pm 0.23$ & $20.9-27.0$ & $24.3^{\mathrm{b}} \pm 0.22$ \\
\hline $\mathrm{pH}^{4}$ & $3.23-3.68$ & $3.44^{\mathrm{a}} \pm 0.03$ & $3.38-3.88$ & $3.56^{\mathrm{b}} \pm 0.03$ & $3.36-4.11$ & $3.70^{\mathrm{c}} \pm 0.03$ & $3.53-4.40$ & $3.95^{\mathrm{d}} \pm 0.03$ \\
\hline $\mathrm{TA}^{5}$ & $4.18-7.27$ & $6.04^{b} \pm 0.20$ & $4.00-8.38$ & $5.25^{\mathrm{a}} \pm 0.18$ & $3.52-7.00$ & $5.16^{a} \pm 0.17$ & $3.45-7.63$ & $4.60^{c} \pm 0.16$ \\
\hline
\end{tabular}

(1)Data shown in $\mathrm{mg} / \mathrm{g}$ berry weight except for Anthocyanins, Total phenols, $\mathrm{B}$, pH and TA;

(2)Anthocyanin in mg malvidin-3-glucoside/g and Total phenols as absorbancy units (A280)/g;

(3)Degrees Brix;

(4) $\mathrm{pH}$ units;

$(5) \mathrm{g} / \mathrm{L}$;

(6)Standard deviation significant at a $5 \%$ level $(\mathrm{p}<0.05)$;

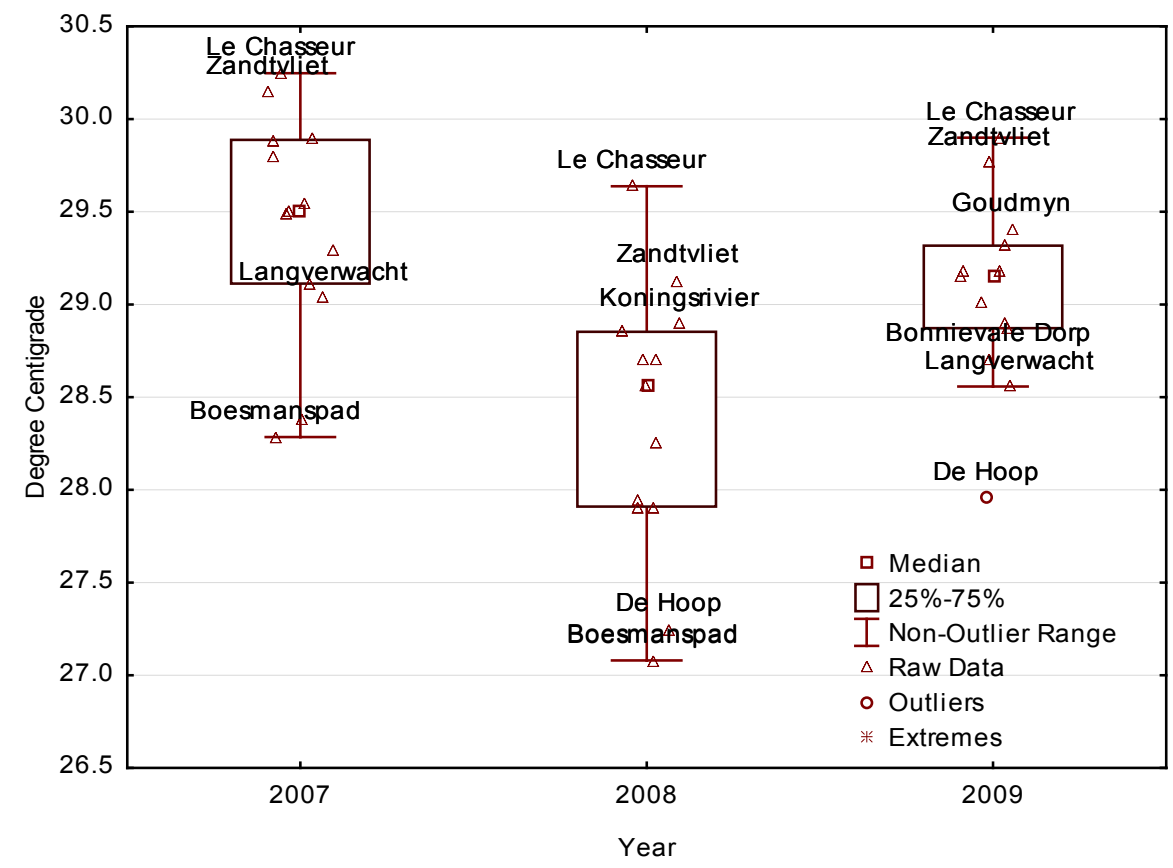

FIGURE 5

The average maximum temperature distribution for Jan to April 2007, 2008 and 2009 from 13 weather stations in the Robertson area. 
Le Chasseur and Zandtvliet weather stations were found to be on the higher end of the average maximum temperature range (29.1-30.2 ${ }^{\circ} \mathrm{C}$ ), while the De Hoop and Boesmanspad stations recorded the lower end of the maximum temperature range for all three seasons $\left(27.0-28.8{ }^{\circ} \mathrm{C}\right)$ (Fig. 5). The Le Chasseur and Zandtvliet stations are close to blocks P8, M6,C1, C6, C11, S1, S7, S8 and P3, M2, C5, C12, S5 respectively and are therefore exposed to the most extreme maximum temperatures every season, while the De Hoop station are close to blocks P7, S9, S10 and represents the lower spectrum of max temperature each season. In some instances the blocks in the higher temperature regions were associated with lower colour and vice versa, but differences in vine water status and microclimate can also play a role.

Another important factor to consider in the development of the grapes during 2008 was the greater rainfall range that was experienced (Fig. 6). Literature indicates that an area with an annual precipitation $<700 \mathrm{~mm}$ is good for grape/ wine quality (which Robertson clearly falls under) and that high rainfall and excessive irrigation lowers quality (Jackson $\&$ Schuster, 1987). In the case of the Robertson region the annual rainfall is so low that irrigation is compulsory and this should be managed correctly during the growing season (Myburg, 2006; Laget et al., 2008). It has been shown in literature that with increased water availability, the $\mathrm{pH}$ and potassium level of must and wine can increase and that anthocyanin and therefore colour can be reduced (Morris \& Cawthon, 1982; Freeman, 1983; Bravdo et al., 1985; Matthews \& Anderson, 1988). In another article irrigation was reported to have had very little effect on the total anthocyanin concentration of grapes (Sipiora \& Gutierriez Granda, 1998).

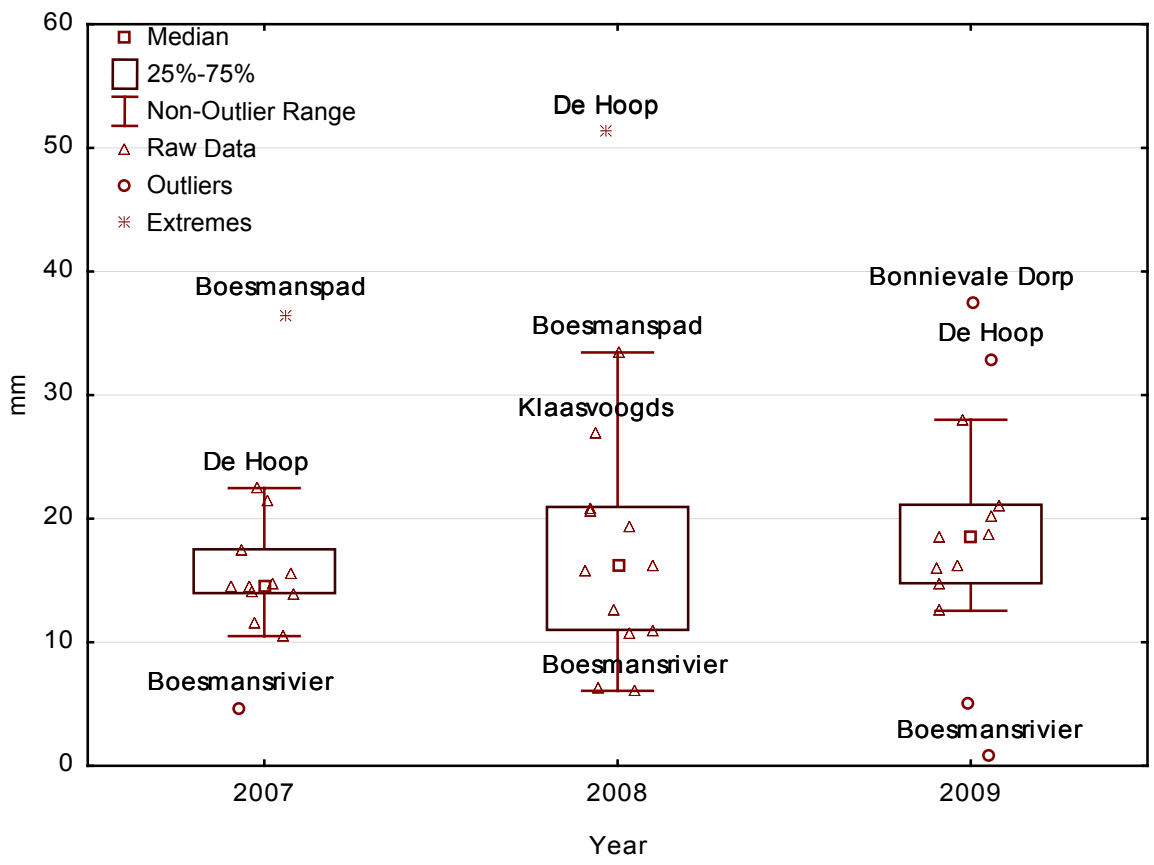

FIGURE 6

Average rainfall and the distribution thereof for the months of January to April during the 2007-2009 harvest seasons.

TABLE 8

A: Blocks that was found to be outliers with respect to the data set, from the aspect of seasons (Refer to Fig. 3).

B: Blocks that were outliers from the 95\% confidence level due to cultivar differences (Refer to Fig. 4).

\begin{tabular}{|c|c|c|c|}
\hline & 2007 & 2008 & 2009 \\
\hline A & \multicolumn{3}{|c|}{ Blocks outlying due to seasonal differences } \\
\hline Pinotage $^{1}$ & P2, P3, P5 & P2 AND P5 & P6 \\
\hline Merlot $^{2}$ & M4, M5, M6 & M2, M6, M7 & M1 \\
\hline Cabernet Sauvignon $^{3}$ & C7 AND C11 & NONE & $\mathrm{C} 8$ \\
\hline Shiraz $^{4}$ & $\mathrm{~S} 3, \mathrm{~S} 4, \mathrm{~S} 5$ & $\mathrm{~S} 1, \mathrm{~S} 5, \mathrm{~S} 6, \mathrm{~S} 7$ & $\mathrm{~S} 4$ \\
\hline B & \multicolumn{3}{|c|}{ Blocks outlying due to cultivar differences } \\
\hline Merlot & M1, M6 & M3, M6, M7 & M11 \\
\hline Cabernet Sauvignon & $\mathrm{C} 1, \mathrm{C} 7, \mathrm{C} 9$ & $\mathrm{C} 5, \mathrm{C} 8$ & $\mathrm{C} 6, \mathrm{C} 8$ \\
\hline Shiraz & $\mathrm{S} 3, \mathrm{~S} 5, \mathrm{~S} 6$ & $\mathrm{~S} 5, \mathrm{~S} 2$ & $\mathrm{~S} 3, \mathrm{~S} 5$ \\
\hline
\end{tabular}

(1)Pinotage blocks: P1-6, 6 Pinotage blocks from different farms in the Robertson area;

(2)Merlot blocks: M1-11, 11 Merlot blocks from different farms in the Robertson area;

(3)Cabernet Sauvignon blocks: C1-12, 12 Cabernet Sauvignon blocks from different farms in the Robertson area;

(4)Shiraz blocks: S1-12, 12 Shiraz blocks from different farms in the Robertson area; 
TABLE 9

Average values of grape parameter data when statistically classified into main groups of orientation, soil and trellis systems of the 47 selected vineyards of the Robertson area.

\begin{tabular}{|c|c|c|c|c|c|c|}
\hline \multirow[b]{2}{*}{ Grape parameter ${ }^{1}$} & \multicolumn{2}{|c|}{ Orientation } & \multicolumn{2}{|c|}{ Soil } & \multicolumn{2}{|c|}{ Trellis system } \\
\hline & Flat & Slope & Karoo & Karoo/Shale & 4WEP & 5WEP \\
\hline Polymeric flavanols & 2.44 & 2.31 & 2.31 & 2.47 & 2.46 & 2.35 \\
\hline Total grape flavanols & 2.58 & 2.45 & 2.43 & 2.62 & 2.60 & 2.48 \\
\hline Free Anthocyanins & 0.51 & 0.56 & 0.55 & 0.56 & 0.51 & 0.53 \\
\hline Total colour pigments & 0.57 & 0.63 & 0.61 & 0.63 & 0.57 & 0.59 \\
\hline Polymeric pigments & 0.06 & 0.07 & 0.07 & 0.07 & 0.06 & 0.07 \\
\hline Total phenols ${ }^{3}$ & 1.23 & 1.25 & 1.20 & 1.21 & 1.16 & 1.34 \\
\hline Tannin & 1.71 & 1.69 & 1.59 & 1.83 & 1.59 & 1.78 \\
\hline${ }^{o} \mathrm{~B}^{4}$ & 23.9 & 23.8 & 23.8 & 23.9 & 23.6 & 23.9 \\
\hline $\mathrm{pH}^{5}$ & 3.70 & 3.68 & 3.69 & 3.71 & 3.69 & 3.69 \\
\hline $\mathrm{TA}^{6}$ & 5.14 & 5.39 & 5.25 & 5.25 & 5.15 & 5.38 \\
\hline RW Grading $^{7}$ & 4.24 & 4.45 & 4.43 & 4.55 & 4.12 & 4.40 \\
\hline
\end{tabular}

(2)Anthocyanins: $\mathrm{mg} / \mathrm{g}$ malvidin-3-glucoside;

(3)Total phenols: $\mathrm{mg} / \mathrm{g}$ absorbancy units

(4) ${ }^{\circ} \mathrm{B}$ : Degrees Brix measured with brix meter

(5) $\mathrm{pH}$ in $\mathrm{pH}$ units;

(6)TA: in $\mathrm{g} / \mathrm{L}$;

(7)RW Grading: Robertson Winery grading numerical value between 1 and 6,1 pertaining to low quality and 6 to high quality;

\section{CONCLUSIONS}

In the Robertson region the average monomeric flavanol level of grapes were found to be much lower than in other studies, despite the wider range. The total grape flavanols were high and could be an indication of the grapes not reaching phenolic maturity, despite the fact that the grapes were otherwise (Sugar, $\mathrm{pH}, \mathrm{TA}$ ) ripe to be harvested. The decision to harvest should be based on the wine style that is desired as well as the sales category the particular wine will fall in. Not only sugar concentration, $\mathrm{pH}$, and TA should be taken into account, but the actual level of phenolic compounds as well. Various publications exist on the actual measurement techniques available to test for phenolic ripeness. The total colour was also found to be lower than that of other studies. This could be due to higher temperatures that slowed down colour development in the berries metabolically. Seasonal impact on the development of colour and phenolic compounds was evident. Cultivar and block differences also had an effect. Some blocks were outliers due to intrinsic differences in their site or rootstock. The use of colour and phenolic data in the Robertson region for the determination of grape quality at harvest is important due to the fact that such great variation occurs. Geographical mapping demonstrated how vastly different the data is through the region. This work can serve as a valuable basis for future research on colour and phenolic characteristics of red grapes in the Robertson area. Follow on research would include whether differences observed between vintages, cultivars and blocks are also reflected in the corresponding wines.

\section{LITERATURE CITED}

Bakker, J., Bridle, P., Timberlake, C.F. \& Arnold, G.M., 1986. The colours, pigment and phenol contents of young port wines: Effects of cultivar, season and site. Vitis. 25, 40-52.
Becker, H., 1985. Wine grape varieties for cool climates. In: Proc. Int. Symp. Cool Clim. Vitic. Enol. Heatherbell, D.A., Lombard, P.B., Bodyfelt, F.W. \& Price, S.F. (eds). Oregon State Uni. Exp. Stat. Tech. Pub. No. 7628. pp. 46-62.

Bindon, K., Myburgh, P., Oberholzer, A., Roux, K. \& du Toit, C., 2011. Response of grape and wine phenolic composition in Vitis vinifera L. cv. Merlot to variation in grapevine water status. S. Afr. J. Enol. Vitic. 32(1), $71-88$

Bramley, R.G.V., 2005. Understanding variability in wine grape production systems (2): Within vineyard variation in quality over several vintages. Aust. J. Grape Wine Res. 11, 33-42.

Bravdo, B., Hepner, Y., Loinger, C., Cohen, S. \& Tabacaman, H., 1985. Effect of irrigation and crop level on growth, yield and wine quality of Cabernet Sauvignon. Am. J. Enol. Vitic. 36,132-139.

De Freitas, V.A.P. \& Glories, Y., 1999. Concentration and compositional changes of procyanidins in grape seeds and skin of white Vitis vinifera varieties. J. Sci. Food Agric. 79, 1601-1606.

Deloire, A., 2011. The concept of berry sugar loading. Wineland Magazine. January, 93-95.

Downey, M.O., Dokoozlian, N.K. \& Krstic, M.P., 2005. Cultural practice and environmental impacts on the flavonoid composition of grapes and wine: A review of recent research. Am. J. Enol. Vitic. 57(3), 257-268.

Du Toit, W.J., Lisjak, K., Marais, J. \& Du Toit, M., 2006. The effect of micro-oxygenation on the phenolic composition, quality and microbial composition of South African red wines. S. Afr. J. Enol. Vitic. 27, 57-67.

Freeman, B.M., 1983. Effects of irrigation and pruning of Shiraz grapevines on subsequent red wine pigments. Am. J. Enol. Vitic. 34, 23-6.

Gonzalez-San Jose, M.L., Santa-María, G. \& Diez, C., 1990. Anthocyanins as parameters for differentiating wines by grape variety, wine-growing region, and wine-making methods. J. Food Comp. Anal. 3, 54-66.

Guidoni, S., Allara, P. \& Schubert, A., 2002. Effect of cluster thinning on berry skin anthocyanin composition of Vitis vinifera cv. Nebbiolo. Am. J. Enol. Vitic. 53, 224-226.

Hanlin, R.L. \& Downey, M.O., 2009. Condensed tannin accumulation and composition in skin of Shiraz and Cabernet Sauvignon grapes during berry development. Am. J. Enol. Vitic. 60 (1), 13-23. 
Harbertson, J.F., Picciotto, E.A. \& Adams, DO., 2003. Measurement of polymeric pigments in grape berry extracts and wines using a protein precipitation assay combined with bisulfite bleaching. Am. J. Enol. Vitic. 54, 301-306.

Hunter, J.J. \& Bonnardot, V., 2011. Suitability of some climatic parameters for grapevine cultivation in South Africa, with focus on key physiological processes. S. Afr. J. Enol. Vitic. 32(1), 137-154.

Iland, P., Ewart, A., Sitters, J., Markides, A. \& Bruer, N., 2000. “Techniques for chemical analysis and quality monitoring during winemaking." (Patric Iland wine Promotions, Campbelltown, Adelaide, Australia).

Jackson, D., \& Schuster, D., 1987. Production of grapes in cool climates. Butterworths, N.Z.

Jackson, D.I. \& Lombard, P.B., 1993. Environmental and management practices affecting grape composition and wine quality-A Review. Am. J. Enol. Vitic. 44(4), 409-430.

Jensen, J.S., Demiray, S., Egebo, M. \& Meyer, A.S., 2008. Prediction of wine color attributes from the phenolic profiles of red grapes (Vitis vinifera). J. Agric. Food Chem. 56, 1105-1115.

Kliewer, W.M., 1970. Effect of day temperature and light intensity on coloration of Vitis vinifera L. grapes. J. Am. Soc. Hort Sci. 95, 693-697.

Kliewer, W.M. \& Torres, R.E., 1972. Effect of controlled day and night temperatures on coloration of grapes. Am. J. Enol. Vitic. 23, 71-77.

Laget, F., Tondut, J.-L., Deloire, A. \& Kelly, M.T., 2008. Indications of climate evolution in a Mediterranean area - considerations for the wine and viticulture sectors. J. Int. Sci. Vigne. Vin. 42, 113-123.

Marais, J. \& October, F., 2005. Relationship between grape colour and wine quality. Wynboer, 2005. 191, 15-17.

Matthews, M.A., \& Anderson, M.W., 1988. Fruit ripening in Vitis vinifera L.: responses to seasonal water deficits. Am. J. Enol. Vitic. 39, 313-320.

Mattivi, F., Vrhovsek, U., Masuero, D. \& Trainotti, D., 2009. Aust. J. Grape Wine Res. 15, 27-35.

May, P. \& Antcliff, A.J., 1963. The effect of shading on fruitfulness and yield of sultana. J. Hort Sci. 38, 85-94.

McCarthy, M.G. \& Cirami, R.M., 1990. The effect of rootstocks on the performance of Chardonnay from a nematode-infested Barossa Valley vineyard. Am. J. Enol. Vitic. 41,126-130.

McDonald, M.S., Hughes, M., Burns, J., Lean, M.E.J., Matthews, D. \& Crozier, A., 1998. Survey of the free and conjugated myricetin and quercetin content of red wines of different geographical origins. J. Agric. Food Chem. 46, 368-375.

Mercurio, M.D. \& Smith, P.A., 2008. Tannin Quantification in Red grapes and wine: comparison of polysaccharide- and protein based tannin precipitation techniques and their ability to model wine astringency. J. Agric. Food Chem. 56, 5528-5537.

Morris, J.R. \& Cawthon, D.L., 1982. The effect of irrigation, fruit load, and potassium fertilization on yield, quality, and petiole analysis of Concord (Vitis labrusca L.) grapes. Am. J. Enol. Vitic. 33: 145-148.

Myburgh, P.A., 2006. Juice and Wine Quality Responses of Vitis vinifera L. cvs. Sauvignon blanc and Chenin blanc to timing of irrigation during berry ripening in the coastal region of South Africa. S. Afr. J. Enol. Vitic. 27(1), 1-7.

Ojeda, H., Deloire, A. \& Carbonneau, A., 2001. Influence of water deficits on grape berry growth. Vitis. 40(3), 141-145.

Ojeda, H., Andary, C., Kraeva, E., Carbonneau, A. \& Deloire, A., 2002. Influence of pre- and postveraison Water Deficit on Synthesis and concentration of Skin phenolic compounds during berry Growth of Vitis vinifera cv. Shiraz. Am. J. Enol. Vitic. 53, 261-267.

Ollat, N., Diakou-Verdin, P., Carde, J-P., Barrieu, F., Gaudillère, J.P. \& Moing, A., 2002. Grape berry development : a review. J. Int. Sci. Vigne. Vin. 36, 109-131.
Ough, C.S., Lider, L.A. \& Cook, J.A., 1968. Rootstock-scion interactions concerning wine making. I. Juice composition changes and effects on fermentation rate with St. George and R99 rootstocks at two nitrogen fertilizer levels. Am. J. Enol. Vitic. 19, 213-227.

Peng, Z., Iland, PG., Oberholster, A., Sefton, MA., \& Waters, EJ., 2002. Analysis of pigmented polymers in red wine by reverse phase HPLC. Aust. J. Grape Wine Res. 8, 70-75.

Peynaud, E., 1996. The Taste of Wine. The Art and Science of Wine Appreciation. $2^{\text {nd }}$ ed. Wiley \& Sons, New York.

Prie, AJG., 1977. Phenolics Accumulation in Red Wine Grapes (Vitis vinifera L.). Thesis, University of Sydney.

Revilla, E., Alonso, E. \& Kovac, V., 1997. The content of catechins and procyanidins in grapes and wines as affected by agro-ecological factors and technological practices. Am. Chem. Soc., Washington, DC. In Wine: Nutritional and Therapeutic Benefits. T.R. Watkins (Ed.). 69-80.

Robichaud, J.L. \& Noble, A.C., 1990. Astringency and bitterness of selected phenolics in wine. J. Sci. Food Agric. 53,343-353.

Romero-Cascales, I., Ortega-Regules, A., López-Roca, J.M., FernándezFernández, J.I. \& Gómez-Plaza, E., 2005. Differences in Anthocyanin Extractability from grapes to wines according to variety. Am. J. Enol. Vitic. $56(3), 212-219$

Rossi, J.A., Jr. \& Singleton,V.L., 1966. Flavor effects and adsorptive properties of purified fractions of grape seed phenols. Am. J. Enol. Vitic. $17,240-246$.

Rossouw, M. \& Marais, J., 2004. The phenolic composition of South African Pinotage, Shiraz and Cabernet Sauvignon Wines. S. Afr. J. Enol Vitic. 25(2), 94-104.

Sarneckis, C.J., Dambergs, R.G., Jones, P., Mercuric, M., Herderich, M.J. \& Smith, R.A., 2006. Quantification of condensed tannins by precipitation with methyl cellulose: development and validation of an optimized tool for grape and wine analysis. Aust. J. Grape Wine Res. 12, $39-49$.

Segade, S.R., Rolle, L., Gerbi, V. \& Orriols, I., 2008. Phenolic ripeness assessment of grape skin by texture analysis. J. Food Comp. Anal. 21, 644-649.

Singleton, V.L., 1987. Oxygen with phenols and related reactions in musts, wine and model systems: Observations and practical implication. Am. J. Enol. Vitic. 38, 69-77.

Sipiora, M.J. \& Gutierriez Grande, M-J., 1998. Effect of Pre-verasion irrigation cutoff and skin contact time on the composition, color and phenolic content of Young Cabernet Sauvignon Wines in Spain. Am. J. Enol. Vitic. $49,152-162$.

Somers, T.C. \& M.E. Evans. 1974. Wine Quality: Correlation with colour density and anthocyanin equilibria in a group of young red wines. J. Sci. Food Agric. 25, 1369-1379.

Turner, J. 2009. http://www.howtodothings.com/home-garden/how-toprevent-grape-growing-mistakes

Van Schalwyk, D., De Villiers, F.E. \& De Villiers, F.S., 1999. The influence of production norms on the wine quality of wine grape cultivars in the Robertson area: Ruby Cabernet. Wynboer article. http://wineland.co.za/ wynboer_archive/recentarticles/1099influence.html

Wang, Z., Deloire, A., Carbonneau, A., Federspiel, B. \& Lopez, F., 2003. Study of Sugar Phloem Uploading in Ripening Grape berry under Water Stress conditions. J. Int. Sci. Vigne Vin. 37(4), 213-222.

Winkler, A.J., Cook, J.A., Kliewer, W.M. \& Lieder, L.A., 1974. General viticulture. University of California Press, Berkeley.

Yokotsuka, K., Nagao, A., Nakazawa, K. \& Sato, M., 1999. Changes in Anthocyanins in Berry skins of Merlot and Cabernet Sauvignon grapes Grown in two soils modified with limestone or oyster shell versus a native soil over two years. Am. J. Enol. Vitic. 50(1), 2-12. 